\title{
The South Africa Meeting of the British Association, I929.
}

$\mathrm{T}$ HOSE members of the British Association who attended the meeting in South Africa in 1905 and propose to attend the Capetown-Johannesburg meeting in 1929 , will find that much change has taken place in the intervening years. Nowhere will the change be more striking than in the places where the meeting will be held. The sites of the University of Capetown and of the University of the Witwatersrand (Johannesburg) may not vie with that of the University of Glasgow, where the meeting was last held, but their sites are nevertheless magnificent, and the accommodation available is sufficient to provide meeting-rooms for all the sections. Both cities, Capetown and Johannesburg, have town halls of large seating capacity for the larger evening meetings which form such a prominent feature of the British Association meetings.

The officers of the Association and the secretariats of the Sections will be housed at both centres in proximity to the meeting places, and it is hoped that this convenience will contribute to the success of the meeting.

The ocean voyage from Southampton to Capetown is one of the finest that can be taken for the length of time occupied : it is accomplished by the mail steamers of the Union-Castle Mail Steamship Co. in sixteen and a half days, the only port of call on the way being Madeira. The intermediate steamers of the same line, and the steamers of other lines, take a few days longer on the voyage.

The mail steamer leaving Southampton on July 5 will arrive at Capetown on the morning of Monday, July 22, and the inaugural meeting will be held in the City Hall on the evening of that day. At this - meeting the assembly will be welcomed by the Mayor of Capetown and will be addressed by the president of the South African Association for the Advancement of Science, his Honour Mr. J. H. Hofmeyr, Administrator of the Transvaal Province. The retiring president, Sir William Bragg, will induct the president, Sir Thomas Holland, who, it is hoped, will deliver a short formal address.

Sessions of the sections will be held on the mornings of July 23-26. During the week, opportunity will be given to visitors to see the beauties of the Cape Peninsula with its unrivalled marine and mountain drives.

The first party, in two special trains, will leave Capetown on the morning of July 28 ; the trains will pass through the magnificent mountain scenery of the Hex River in daylight and will reach Kimberley on the following morning. The day will be spent in the Diamond City, where the visitors will be the guests of the De Beers Consolidated Mines, Ltd. Leaving Kimberley in the evening, the party will arrive in Johannesburg on the morning of July 30. The second party will leave Capetown on the morning of July 29 and, following the same route and programme, will arrive in Johannesburg on the morning of July 31 .

The Johannesburg session will begin on July 31 and will be continued until Aug. 3. The presidential address will be delivered on the evening of
July 31. During the week, visits to gold mines and to points of interest in the neighbourhood will be arranged.

It is proposed that some of the sectional presidential addresses shall be delivered at Capetown and that the remainder will be delivered during the second part of the session. Provisionally, it has been arranged that at Capetown the presidential addresses of Sections A (Mathematical and Physical Sciences), B (Chemistry), E (Geography), I (Physio$\operatorname{logy}$ ), J (Psychology), and L (Educational Science) will be delivered. The presidential addresses to be delivered at Johannesburg will be those of Sections D (Zoology), F (Economic Science and Statistics), G (Engineering), H (Anthropology), and K (Botany)

The fifteenth International Geological Congress is to be held in Pretoria on July 29-Aug. 7. Overseas members of the Congress will arrive in Capetown on July 15 and, after spending three days there, will proceed, by different routes and by easy stages, to Pretoria, which will be reached about July 28. Arrangements are being made for the second part of the session of Section C (Geology) to be held in Pretoria in association with the International Geological Congress; it is, however, definitely decided that the Section meetings are not to be merged in those of the International Congress, but that the two will take place simultaneously.

The Pan-African Agricultural and Veterinary Congress begins in Pretoria on Aug. 2, and it is intended that the second part of the session of Section M (Agriculture), at which the presidential address will be delivered, shall be held in Pretoria in conjunction with the Agricultural Congress. Pretoria can be reached from Johannesburg in about an hour either by road or by rail.

At the conclusion of the Johannesburg (and Pretoria) session, members may proceed direct to Capetown for the return voyage ; leaving Johannesburg on the evening of Aug. 7, Southampton can be reached by mail steamer on Aug. 26. For those visitors who can afford the time, a wide choice of organised tours through South Africa and Rhodesia will be offered. The tours will permit visitors to see Rhodesia (Victoria Falls, Matopos, Zimbabwe Ruins), Eastern Transvaal (Sabi Game Reserve, White River Citrus Fields, Barberton Goldfields), Natal, Orange Free State, and Eastern Province (Cape). Arrangements will be made whereby members may embark at Lourenço Marques (Portuguese East Africa) or at Durban for the return voyage to Europe by the east coast of Africa route, or at Durban, Port Elizabeth, or Capetown for the return voyage by the west coast route.

As some of these tours will entail a considerable time being spent in the train, it may not be out of place to remark that, in spite of the narrow gauge of the South African railways, travelling is comfortable (apart from annoyance by dust), and the sleeping arrangements in the roomy coaches are satisfactory. 
The meeting takes place during the South African winter. Capetown is in the climatic region of winter rains : for the period during which sessions will be held in Capetown the mean maximum temperature is $62^{\circ}$ and the mean minimum is $48^{\circ}$, the average rainfall being about 2.5 inches per month. About ten hours by rail from Capetown the train will cross the line dividing the region of winter rains from that of summer rains.
Kimberley, Johannesburg, and Pretoria lower temperatures will be experienced than at Capetown, but clear skies and brilliant sunshine normally prevail during the season at which the meetings are to be held.

Local arrangements for the meeting are in the hands of the South African Association for the Advancement of Science and every endeavour is being made to ensure the success of the meeting.

\section{Christmas Customs and their Origins.}

$\mathrm{O}^{\mathrm{F}}$ F the popular customs associated with Christmas, few have a Christian origin. The aim of the early Church was to distract its followers from the great festivals of the heathen, and consequently pagan elements were allowed to be incorporated as freely in the observance of Christmas as they were in the other major feasts of the Christian calendar. Here the pietistic sentiment of the Mediterranean peoples has tended to preserve the mystic element of paganism rather than the saturnalian. Hence the devotion to the Midnight Mass; and, as the cult of the Madonna enshrines the popular memory of the great pagan mother goddess, so the Cave of Zeus, of Adonis, and of Mithra survive in the cult of the Manger, in which both in the representations in the churches and in the popular shrines in the Italian streets, Mary, Joseph, and the animals kneel in adoration of the Child. ${ }^{1}$ In Spain the Manger is set up even in private houses, where one or two rooms may be set aside for the purpose. In England the cult may be traced in the belief, once common in the west country, but not confined to that area, that at twelve o'clock on Christmas Eve the oxen kneel in their stalls. A connexion, with more than a flavour of paganism, may also be inferred in the divinatory custom of placing a cake on the head or horns of an ox in its stall on Christmas Eve, once practised in Herefordshire and other western counties and in the north, the prosperity of the coming year being foretold by the direction in which the cake fell or was shaken off. To the Manger cult may also be aseribed the 'vessel cup' of northern England, a box or framework, usually decorated with evergreens, containing a doll, or more often two dolls representing the Madonna and Child, which was carried from house to house by 'vessel cup' women or children. In the name "vessel cup," a corruption of 'wassail,' northern paganism combines with that of the south.

Among northern races, Christmas observances take on a different character from those of the Mediterranean area. Here Christmas coincided with the mid-winter feast of Yule, and popular custom, on the whole, has tended to emphasise the joyous nature rather than the solemnity of the observance. Harsher climatic conditions demanded a greater act of faith to believe in the return of the sun, and the rejoicing at the winter solstice when the sun god turned to his upward path was more

A strong Nationalist movement is now endeavouring to revive the Manger and displace the imported Christmas Tree, which is also denounced by the clergy. strongly marked to a corresponding degree. In England, in particular, the festival, it was noted by early travellers, was kept up with greater zeal than in any other country. Here Christmas is Yule, and Mediterranean conceptions, though not absent, have relatively little influence.

The feast of Yule, though associated with certain of the northern deities, was in its origin a midwinter feast of sun worship, in which the characteristic features were rejoicing at the passing of the solstice, the sacrificial meal, and observances of a magical character to ensure the fertility of the coming year. Traces of all these survive in Christmas practice. There is also another aspect of the yule feast which has to be taken into account. It was a feast of the dead, and therefore a time of peril, when harm from their spirits must be averted. It was the time when the 'wild huntsman' rode with his hounds. Hence, even in Scotland, where the observance of Christmas is ignored, and at one time was made subject to penalty, divinatory and good luck practices were followed, similar to those of New Year. A dark man must be the first to enter the house in the morning, something should be brought into the house during the day, but nothing, especially fire, must be taken out or given away, and so forth. In Scandinavia everything in the house had to be left tidy and the tables laid for the Christmas meal before the family went to church, as the spirits of the dead came to inspect while they were away. Sometimes at the Christmas feast a special table was set aside for the spirits of the dead. Thus was prosperity ensured in the coming year.

In England a group of closely related customs connect Christmas with a feast of the dead. These are the yule log or yule clog, the yule candle, and the yule cake. The custom of the yule log was widespread-a huge block of wood was brought in with ceremony-sometimes it was provided by the overlord from the manorial woods-and was ceremonially lighted at a ritual hour on Christmas Eve and allowed to burn through the Christmas festivities. The sacred character of the fire is indicated by the injunction that the hands of the maid tending it must be clean; otherwise it will go out. A fragment of the $\log$ should be preserved for good luck and to light the next year's log, so that old and new might burn together. If the house of a neighbour caught fire, a piece thrown on the flames extinguished them. The yule candle was also lighted at a stated time on Christmas Eve. It should never be snuffed or put out, and no other

No. 3086, Vor. 122] 